\title{
RE-EXAMINING THE OBJECTS OF MYSTICAL REALITY
}

\author{
Sarena Abdullah \& Chung Ah Kow \\ School of the Art, Universiti Sains Malaysia, Penang \\ (sarena.abdullah@usm.my, cikguchung@gmail.com)
}

\begin{abstract}
In the 1960s, when Malaysian artists seemed to be influenced by the Abstract Expressionist art movement of the West, a group of Malaysian artists known as the New Scene were interested in the "cerebral and impersonal", analytical and constructivists aspects of art making. They were mostly interested in space, colour and materials that were exhibited in art exhibitions such as The New Scene, experiment '70, and Dokumentasi 72. Only the partnership of Redza and Sulaiman Esa, in their effort to provide an alternative aesthetic to the Abstract Expressionists, lasted. Both artists' propositions on objects of real time and space were presented in the exhibition Towards a Mystical Reality in 1974 in which they took over the role of the critic by framing their own propositions, ideas, and concepts written in the manifesto published in conjunction with the exhibition. This essay attempts to discuss random objects without any aesthetic value selected by these artists as works of art by employing Dickie's Institutional Theory. Furthermore, it will examine a few aspects from the theory that justify the exhibition and its content as art and thus argue that it has its own aesthetics that demand our own contextual analysis and understanding.
\end{abstract}

Keywords: Mystical Reality, Redza Piyadasa, Sulaiman Esa, George Dickie, Institutional Theory

\section{Introduction}

Malaysian art today have shifted in terms of its artistic approaches as more and more artists are working beyond the traditional compartmentalization of fine arts (Abdullah, 2011). These new works, are of a different type. Leaving the less clearer direction of artists in the early years of Malaysia's post-Independence (Abdullah, 2010b), leaving the well-espoused Abstract Expressionists of the 1960s and Malay/Islamic-centered art of the 1970s and 1980s. Malaysia art in the last two and 
a half decade embraces a more universal subject, inter-discipline in terms of its artistic approach. The eclecticism and the complexity of art making today can be traced as early as during the 1970s, when a group of Malaysian artists known as the New Scene were interested in the "cerebral and impersonal", analytical and constructivists aspects of art making - akin to Minimalist art espoused by artists like Carl André, Dan Flavin, Donald Judd, Sol LeWitt and others. These interests were presented in art exhibitions such as The New Scene, experiment '70, and Dokumentasi 72 and Towards a Mystical Reality: A Documentation of Experiences Initiated jointly by Redza Piyadasa and Suleiman (sic) Esa (1974).

Only the latter Towards a Mystical Reality: A Documentation of Experiences Initiated jointly by Redza Piyadasa and Suleiman (sic) Esa (or in this essay will be referred to as the Mystical Reality) held in 1974 has been examined and discussed recently as an important exhibition in the Malaysian art scene. Mystical Reality was an exhibition held at Sudut Penulis (Writer's Corner) of Dewan Bahasa dan Pustaka and it was the first and the only Malaysian exhibition that was accompanied by a 31-page manifesto akin to the manifestos produced by European artists in the early $20^{\text {th }}$ century. Although the exhibition did not bring direct impact on the development of modern art in Malaysia, in the study of art history, the exhibition is important as one of the initial catalyst that brought about changes to the acceptance of conceptual ideas into the practice of Malaysian art (Abdullah, 2008; 2010a; Mashadi, 2007; Soon, 2013).

The main contribution of the exhibition was based on the fact that it was initiated and produced based on its conceptual premises. While the appreciation and importance of this exhibition have been discussed, especially in terms of its conceptual premise, this paper will focus on the legitimacy or authenticity of the works of this exhibition based on the perspective of Institutional Theory as espoused by George Dickie. Before we proceed with the argument, it is best for us to first discuss the exhibition itself.

\section{Mystical Reality, a Jointly Initiated Experience}

In the late 1960s, a few Malaysian artists had begun to advance the idea of an 'alternative aesthetic' based on the premise that art should be cerebral-centred rather than emotion-centred and this has accumulated in the works of artists that have been influenced by the Hard Edge or Conceptual Art such as Redza Piyadasa, Sulaiman Esa, Tan Teong Eng, Tan Teong Kooi, Tang Tuck Kan and Choong Kam Kow. Artists promoting these perspectives in Malaysia at that time included those who had arrived in Britain in the mid-1960s and witnessed a change in the principles of art education in the United Kingdom where several leading English art colleges that had introduced 'Basic Design' subject founded based on the Bauhaus pedagogy. ${ }^{1}$ While these new approaches were not uniformly 
or simultaneously implemented across all art colleges in England, much of the agitation for change in art education was initiated by Hornsey College of Art in London, in which two Malaysian artists, Sulaiman Esa and Redza Piyadasa were enrolled. The cerebral-centred versus emotion-centred art discourse can be traced in how these artists attempted to challenge and displace the Abstract Expressionist ${ }^{2}$ aesthetic as exhibited in the GRUP exhibition and The Expressionists of the 1960s. In the 1960s and even until today, Abstract Expressionism has been one of the Western art movements that has influenced many Malaysian artists despite the fact that most of the content or subject matter were local (Abdullah, 2013: 455-465).

Redza Piyadasa, Sulaiman Esa and a few other Malaysian artists as listed above have consistently initiated the so-called 'alternative aesthetics' in which is characterized by its 'cerebral and impersonal' approach in exhibition such as The New Scene'69 (1969), experiment '70 (1970), dokumentasi 72 (1972) and Mystical Reality (1974). Eventually, Mystical Reality became the pinnacle of both Sulaiman Esa and Redza Piyadasa's attempt in shifting the perspectives of Malaysian artists at that time. Even though it may be argued that such conceptual attempts had already begun with The New Scene '69, the Mystical Reality manifesto claims to reject all previous developments in Malaysian art (Piyadasa \& Esa, 1974: 6). However, despite this claim, various aspects of the exhibition and manifesto reveal that the exhibition was, nonetheless, still an extension of dokumentasi '72, and to an extent, of experiment '70. This is particularly evident when considering the premise the artists promoted -- a context of art concerned with actual space, time and light and its reference to Zen and the premise of the Conceptual art approach, which had been flagged by these two previous exhibitions before. In the exhibition, the artists put up everyday objects or artifacts to highlight the concept of ephemerality based on Zen/Taoism ideology.

Besides that, the artists managed to make the ideational premise of the work known through their manifesto, in contrast to other artworks of that time which attended almost exclusively to its appearance. The manifesto extensively outlines its structure, in which the artists frame their own propositions, ideas and concepts to the public. In the manifesto of the exhibition, Piyadasa and Sulaiman Esa (1974) outlined the underlying thoughts of Malaysian artists in the 1960s and early 1970s. They wrote about the dilemma faced by the artists in Malaysia in their search for a national identity. They also criticized the local artists whom they consider as imitating Western art. Their stance is anti-formalist and anti-aesthetic, against various other artists whom at that time were mostly producing Abstract Expressionist artworks. In the premises of their conceptual work, they stated, 'We had abandoned illusionistic devices altogether by 1971 and had become involved with actual space, actual time and actual light.' (Piyadasa \& Esa, 1974: 8). 
The alternative models as espoused by Sulaiman Esa and Piyadasa followed the Eastern philosophy, or so they claimed. T.K. Sabapathy in the "Introduction" explained that Redza Piyadasa and Sulaiman Esa have put themselves in a position of confrontation that deals between Eastern artistic practices and Western artistic practices, but highlighting new artistic approach that is derived from the mystical and philosophical traditions rooted in Asia, Taoism and Zen, in particular. This alternative approach that they assert consciously, seeks to replace the Western artistic model, which is based on humanism and scientific empiricism spirit. Sabapathy said that their attempt to reflect on the expectations of Asian artists reached the level that art is based on something that is real or 'art = reality' (Sabapathy, 1978: 33). This perhaps could restore the Asian values as the main subject, especially for Asian artists and it could also lay the foundation for artists in examining local realities in which could also be investigated in the context of arts (Sabapathy, 1994: 68).

The exhibition, however, was not well received and became somewhat become polemical. The polemics were primarily based on the way the manifesto was written and the premise suggested by the artists. During the opening of the exhibition, Salleh ben Joned unzipped his trousers and urinated in another corner of the exhibition space as part of his protest of the 'premise' of the exhibition. One year later, polemics on the event was published in Dewan Sastra magazine by authors such as Siti Zainon Ismail, Redza Piyadasa, Ponirin Amin and Salleh ben Joned, who voiced their opinions about the event (Amin, 1975, Ismail, 1975, Joned, 1975, Piyadasa, 1975). It must be noted here that the 'premise' of the exhibition was criticized by Salleh, Siti Zainon Ismail and Ponirin Amin while Redza Piyadasa defended the objective of the exhibition.

The objects or artifacts exhibited, however, due the fact that the objects chosen did not fit the idea of what an artwork should be (or not), have been left unexamined. Therefore, this paper is an attempt to examine how the objects or items listed in the previous section are works of art. On the other hand, this paper, will not further discuss the cerebral, conceptual premise, the Zen aspect or even the manifesto of the exhibition. The question that will be discussed in this paper is why found objects or termed as 'artifacts' as listed above are works of art? The answer to this question is vital, especially for those who are not familiar with the historical development of modern art. It must be noted that the exhibition itself has not been well received from certain quarters.

\section{Examining Mystical Reality}

In this essay, we will discuss Mystical Reality and the acceptance of the objects that were exhibited as artwork by using Dickie's Institutional theory. Reading the list of objects that was exhibited in the exhibition, one would wonder how randomly 
collected objects or artifacts could be regarded as artworks. It must be noted, however, that this is not the first case that random objects have been conferred as art objects though this was the first attempt in Malaysia. The attempt to use everyday objects or what was termed as 'readymades' by Marcel Duchamp as works of art has superseded Mystical Reality about fifty years ago. The Western art world in the mid-1960s consists of what Arthur Danto called the 'mere things'. This development in the Modern art context resulted in the difficulty of picking out artworks from non-artworks, since the art that was produced resembled or consisted of non-artworks.

George Dickie is a professor of philosophy who proposed the Institutional theory in order to explain the forms of contemporary art in the post-modern era in Euramerica. In his works, Dickie argues that art actually exists in a larger social institution as works of 'art' when it has been conferred. Only then the object is considered valid and worthy to be treated like a piece of art. He has rejected the earlier theories of art such as imitation theory as espoused by Plato and expression theory as proposed by Clive Bell. He argues that these theories cannot explain the works of art that accepts the elements of inadvertence or chance as the nature of the artworks and even the non-objective artworks such as those produced by artists like Jackson Pollock, Willem De Kooning, Mark Rothko, Victor Vaserely, Frank Stella, Dan Flavin and others (Dickie, 2007: 220).

It must be noted that, Imitation theory refers to the works of art that can be identified by its function as a representation of the subject, whether through media such as painting, sculpture, literature or music. The existence of works of art such as paintings that does not denote or represent objects (or non-objective) shows that imitation is not a mandatory element in a work of art. The failure of the Imitation theory in understanding the nature of non-objective artworks has spawned debate. In the context of various proposed theories of art, Institutional theory as suggested by Dickie on the other hand has enlightened our understanding of art that cannot be explained by imitation and expression theories.

Dickie extended the theory of the 'artworld' that has been proposed by Arthur C. Danto. Arthur C. Danto, in his book Transfiguration of the Commonplace, sheds some light on the dilemma in the current art world where aesthetics or beauty is no longer the main characteristic of arts anymore. In the 1960s, more art works that consisted of what Danto called 'mere things,' were produced. This development resulted in the difficulty of picking out artworks from non-artworks, since such art works resembled or consisted of non-artworks. Danto's contribution to the discourse is by finding a definition which is not only consistent with radical disjunctiveness of the class of artworks, but explains how the disjunctiveness is possible as well (Danto, 1996: 284). 
In the process of searching for a definition of sound art, Danto examined the exhibition of works such as "Brillo Box" (1964) by Andy Warhol and "Bed" (1955) by Robert Rauschenberg and writes,

'To see something as art requires something the eye cannot descry an atmosphere of artistic theory, a knowledge of history of art: the artworld.' (Danto, 2007: 214)

According to Danto, what distinguishes an object as an artwork is subjected to two cases: first, theories of art and the second, the artworld. Arising from that viewpoint, Dickie expands his view and argues that that the artword is actually in a social institution that cannot be seen by the outward eye. Dickie compares Danto's term 'the artworld' with the wider arts institution with an example of the art of theater that existed since the Greeks to the present. He gives the example of a system such as performance or theater that must be represented by the writers, management crew, the casts and the audiences. Even the script of the plays must be written and produced within the theater-world framework. Dickie uses the simple definition of 'institution' taken from the Webster's New Collegiate Dictionary - '3. That which is instituted as: a. An established practice, law, custom, etc., b. An established society or corporation.' Therefore, according to Dickie, similarly in the example of the theater-world framework -- that there must be a common convention in the production of the artwork, in which the works will be displayed (Dickie, 2007: 221).

Dickie argues that the existence of a framework in the the artworld allows an object that may not be considered as a work of art to be accepted as a work of art. So when Marcel Duchamp submitted a urinal to an art competition on display as 'works of art' in 1917, several things happened at the same time - first, the status of 'art' has been conferred to the object which initially did not have any special value and is not any different from the urinal sold in stores.

It must be noted that the nature of the work (or its properties) and the beauty of an artwork is usually the main focus in a normal exhibition context. In such 'normal' context, only the values of the representations or expressions generated by the work are being appreciated by the audience. Whereas the intangible nature of the work that cannot be exhibited or what is termed as the 'non-exhibited properties' are usually neglected. In the context of Duchamp's work, Dickie argued that Duchamp has acted indirectly as an agent of the artworld and has conferred the status of 'works of art' to the urinal. So in that circumstance, the audience is forced to accept the urinal as an art work. Dickie, however, viewed that the process of conferring an object as an art work within the framework or artworld as something that is actually more flexible as it covers a wider art system that was put forth by Danto (Dickie, 2007: 222). He argues that the act of 
conferring of an artwork can occur based on the definition of 'artwork.' Dickie puts forth his definition of this term in the form of classificatory. A work of art according to him is, first, an artifact and second, sets of aspects of the work conferred with the status of art on behalf of a particular institution in the art world.

The second condition has four interconnected notions (1) [someone] acting as the representative of the art world (2) [the act of] conferring status of the artwork (3) [artifacts] as a candidate and (4) appreciation [by the audience]. The first and the second notion can be exemplified with the act of a king conferring a knighthood, the power of a judge in passing a ruling, or the conferring of Ph.D. to a candidate by the university. However, according to Dickie, in any artworld or institutional contexts, the conferring of a work to an art status does not necessarily exist via certain formal legislation, but it can also take place in an informal way. The conferring of the status of 'art', for example, can be made by those who are involved or play a role in the artworld. It can be artists, writers, composers, film directors and museums, critics, art historians, art lovers and others (Dickie, 2007: 223). What is important here for Dickie, is the context in which the artifacts are on display or being a candidate. The act that a plumbing equipment salesman displays his urinal over the counter in stores is different than Duchamp exhibiting the same urinal in the gallery. Duchamp's work is recognized as a work of art because it was a candidate in which it was conferred by the artists and the act of conferring happens within the artworld support system. The selected objects on display have been consciously presented and the way the artwork was created (by the factory) is not a question. The next criterion is appreciation that demands the audience to accept, understand and appreciate the work (Dickie, 2007: 223-224). As Marcel Duchamp said:

'All in all, the creative act is not performed by the artist alone; the spectator brings the work in contact with the external world by deciphering and interpreting its inner qualification and thus adds his contribution to the creative act. ...' (Lebel, 1959: 78)

Therefore, the audience also plays an important role in the relationship as described above.

Duchamp, who was also the protagonist of the Dada movement, has brought about the ideas that bring forth the issue of anti-art and rebellion against the art in terms of aesthetics, meaning and purpose. In the context of the Mystical Reality as posited in this essay, Piyadasa himself refers to Duchamp. He writes in praise, 
'Duchamp will perhaps emerge as the greatest artist in the twentieth century on the strength of what he single-handedly achieved as early as 1913-1915 - debunking the myth of the art-establishment.' (Sabapathy, 1978: 12)

If 'Fountain' (1917) by Duchamp can be accepted on the basis that its art status was conferred, works by Piyadasa and Sulaiman Esa in the Mystical Reality exhibition have features that work in tandem with 'Fountain' -- although they are different in terms of reasons and directions.

In the exhibition, the artists put up everyday objects taken from their original settings in the exhibition space as a means to promote the concept of ephemerality based on Zen/Taoism ideology (Figure 1). They advocated a new way of confronting reality based on how the audience should 'conceive' reality through concepts rather than 'seeing' things through the visual or retinal sphere. All of these can be understood in how they posited the title or the lists of artifacts or objects of their works:

A list of artifacts or objects that were exhibited in the exhibition:

1. Empty bird cage after release of bird at $2.46 \mathrm{pm}$ on Monday $10^{\text {th }}$ June 1974 (Figure 2).

2. Potted plant watered and looked after by the two artists over a period of seven months.

3. Empty chair on which many persons have sat on.

4. Two half drank Coca Cola bottles.

5. An outlined area occupied by the shadow of the poet Usman Awang made at 4.05 pm on Saturday 8 $8^{\text {th }}$ December 1973. 36"X36"

6. Empty canvas on which many shadows have already fallen. 1974. 36" X $36^{\prime \prime}$

7. Discarded silk-screen which was used to make many beautiful prints.

8. Burnt out mosquito coils used to keep away mosquitoes on the night of 25 $5^{\text {th }}$ March 1974.

9. Discarded raincoat found at a Klang rubbish dump at $4.23 \mathrm{pm}$ on Sunday $13^{\text {th }}$ January 1974 that must have belonged to someone (Figure 3)

10. Randomly collected sample of human hair collected from a barber shop in Petaling Jaya. 


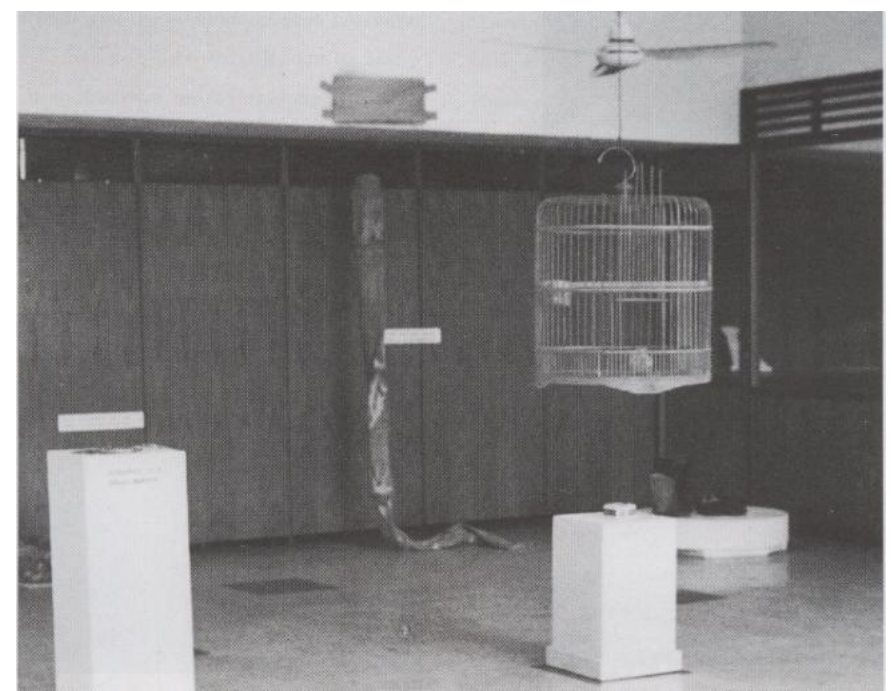

Figure 1: Redza Piyadasa and Sulaiman Esa, "Mystical Reality" (1974). View of Mystical Reality exhibition held at Dewan Bahasa dan Pustaka, Kuala Lumpur.

(Source: Vision and Idea: Relooking Modern Malaysian Art. 1994. Kuala Lumpur: National Art Gallery)

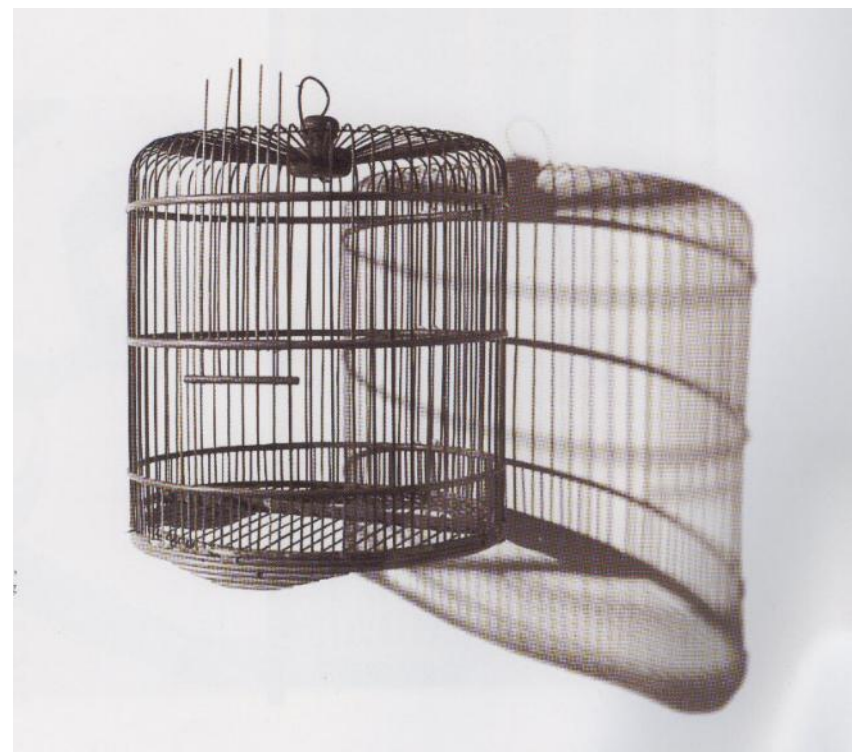

Figure 2: Redza Piyadasa and Sulaiman Esa, "Empty Bird-Cage After Release of Bird" (1974). View of Mystical Reality exhibition held at Dewan Bahasa dan Pustaka, Kuala Lumpur.

(Source: Vision and Idea: Relooking Modern Malaysian Art. 1994. Kuala Lumpur: National Art Gallery) 


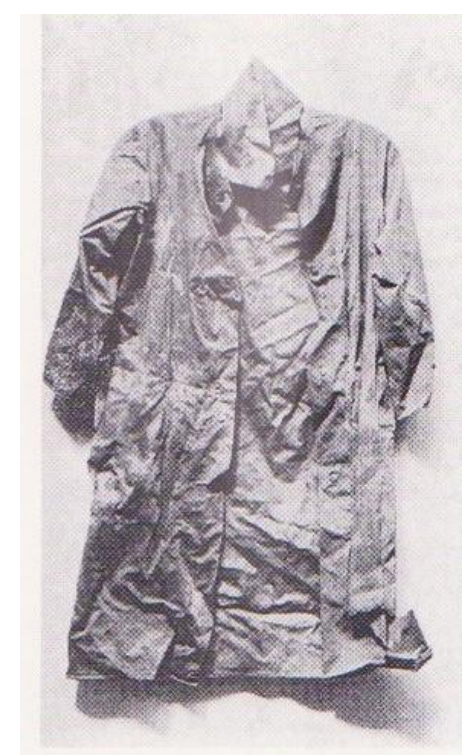

Figure 3: Redza Piyadasa and Sulaiman Esa, "Mystical Reality" (1974). Discarded raincoat found at a Klang rubbish dump at 4.23pm on Sunday 13th January 1974 that must have belonged to someone (discarded after the exhibition).

(Source: Towards a Mystical Reality: A Documentation of Jointly Initiated Experiences by Redza Piyadasa and Suleiman Esa. 1974. Kuala Lumpur)

Based on the theory of imitation and expression, all of these objects exhibited by Piyadasa and Sulaiman Esa, do not have the quality that an artwork should have based on their physical look. They explained,

"The realization that the "object" is really an event draws the spectator's attention to the fact that it exists within a continuum just as he does. The realization that he and the 'object' are both processes existing in time results in a breaking down of the essential differences between the "thing" and "the person". In a sense, both are essentially energies in an infinite situation.' (Piyadasa \& Esa, 1974: 22).

Such listings of objects to be presented in an exhibition setting without being artistically manipulated are odd and are not all in tandem in the general understanding of what forms an artwork during that time. The duo, however, had chosen the objects as the candidate of works of art and the objects were displayed in a place related to the institutional context of art. Thus, the conferring process occurred either formally or informally by various institutional agents -- the Dewan Bahasa dan Pustaka (that function as a gallery space), artists, dignitaries, administrators, writers, as well as the audience or visitors as agents of the art 
world. These people have either directly or indirectly conferred the status of art to the objects by attending the exhibition and being a part of the exhibition itself.

Piyadasa and Sulaiman Esa first, should be seen as the agents and spokesmen who have played roles as a representative of the artworld and that had conferred the status of 'art' to the objects on display during the Mystical Reality exhibition. This was further supported by their preexisting roles and positions in the Malaysian art world at that time - both were very competent artist and vocal critic of the art scene in Malaysia. Their roles were further consolidated by writing a provoking manifesto that is being distributed during the exhibition.

The interference or intervention by Piyadasa and Sulaiman Esa by selecting the objects and positioning or exhibiting them in the context of a gallery had also initiated the objects or at least acted as catalyst for the audiences' mind in appreciating objects as an artistic idea. This is further supported by the attendance of people in the art scene at that time -- their discussion on the displayed works and even the premise of the exhibition through the manifesto could also be argued as overlapping with the functions of the art institution that had conferred the status 'works of art' to the works on display. Piyadasa and Sulaiman Esa acted as a trigger or 'initiators' of a mental process that occurs among the audience or visitors due to the fact that they are in a situation that has already being planned in advance. The goal is to get meditative empathy from the audience to be aware of the power of reality in which the audience has become a part of. The end product of the process, however, depends on the thinking experience that takes place in the mind of the audience (Piyadasa \& Esa, 1974: 21).

The brave exhibition in the context of the development of modern art in Malaysia however, has a totally different purpose from Dada. The selections of objects that complete the Mystical Reality artifactuality element are, however, different from Duchamp's 'readymade.' Duchamp exhibited 'readymades' such as urinal, clothes hanger, shovel and a bicycle wheel. Mystical Reality, on the other hand, delved into the deeper beliefs of the eastern traditions and suggests new interpretations of the role of the artist. Taking the example of the dalang, the shadow puppet player, Piyadasa associates the role of the artist as a mediator or liaison between the audiences and his work (Piyadasa \& Esa, 1974: 16).

The continuum, however, in this case, in which the object and the viewer coexist were placed in two different constructs are -- firstly, the Western perspective (spatio/temporal/sensorial) and second, the Eastern perspective (mental/meditative/mystical). Mystical Reality demanded the audience within the construct of Dickie's theoretical framework to not only have the intellectual capacity that enables a formal appreciation, but also mystical awareness in order to be able to understand the form of sensorial perception itself.

Their main argument in the manifesto is that scientific and empirical point of view that comes from the West is only one reality from many other different 
perspectives (Piyadasa \& Esa, 1974: 16). Largely attributed to this view, the manifesto is trying to lay the foundation of art activities on the basis of the mystical and philosophical Taoist/Zen exists in the East despite it is being far from the concept of national culture and the core beliefs of Malaysians at that time. They explained;

'Taoist thinking concerns itself with the understanding of life and reality directly instead of in the abstract, linear terms of representational thinking.' (Piyadasa \& Esa, 1974: 18)

Piyadasa and Sulaiman Esa included elements of time or time in the context of selected artifacts. They wrote, 'The Taoist/Zen tendency to view object as an "event" rather than as 'form' presupposes that objects existence within an interrelated field or continuum. Time, in this case is a 'mental' time that cannot be measured for all measurements, can only remain relative.' (Piyadasa \& Esa, 1974: 19). They felt that the concept of time or space, as practiced in the West are indeed in contrast with the intrinsic concept of the Eastern time and this has not been explored or understood by Eastern artists.

'The western artist's attempt to create works which exist 'within the viewers own space' then must be quite redundant to the oriental artist. Similarly, the commonly held notion amongst so many "Kinetic" artist that their works are only active when 'switched on' would seem very naïve to the Taoist. Whereas, the western artist has tended to envisage time through "physical" action, the oriental artist feels it mentally. It is essentially a very metaphysical concept of time that the oriental artist deals with!' (Piyadasa \& Esa, 1974: 20)

Thus, the works on display do not only display the aesthetic arrangement in line with the concept of beauty, harmony, structure, style, symbolism or techniques. What is required from the audience is awareness of the mental time but not in the shape or form. They cited the views of Mario Bussagli in his book Chinese Art that explains, for Chinese artists, plants and animals do not only exist as a form of physical existence, but it has a relationship with something that is uncertain and cannot be defined. This is consistent with the nature that Chinese artists believe to have mystical elements. Believing in the union in nature, Eastern artists reject the static and limited happening at one time (Piyadasa \& Esa, 1974: 19).

Evidently, their writing through the manifesto has rejected the concept of Western physical time that can be activated or de-activated (switched on/switched off) with respect to kinetic works by artists such as Naum Gabo, László MoholyNagy, Alexander Calder, Jean Tinguely, Julio Le Parc, Nicolas Schöffer, Takis and 
many others. The duo do not only highlight the physicality elements of the artifacts or objects that are potential to be conferred as an art object as done by Duchamp but also incorporate elements of Eastern time mental and metaphysical nature that should be felt mentally (Piyadasa \& Esa, 1974: 20).

In tracing the early artistic inclination of Redza Piyadasa, the artist explained that his early works examined the involvement of actual space in art and denied any attempt to create symbols. His interest in 'reality' could be traced in his works earlier in even during the dokumentasi 72 exhibition which he pointed out that the fact that there should be no demarcation lines between illusion and reality or the painting and the space occupied by the painting (Piyadasa, 1972: unpaginated). In the catalogue, he explains,

'There is something very religious about my obsession with actual space. It is almost metaphysical. The emptiness and the detachment are reminiscent of the spirit of Zen. The Zen garden, sand arranged in furrows and a few rocks, is the image of stillness. The more still our position and the less disturbed the immediate environment, the greater the possibility of the deepest penetration of reality. This is exactly what meditation is really about. ...' (Piyadasa, 1972: unpaginated).

\section{Conclusion}

The exhibition was forgotten over time as it was just a hara-kiri and it has not made a deep impact on Malaysian arts in general and Malaysian artists in particular -the exhibition is important in the context of art history as an initial attempt by Malaysian artists in trying to change Malaysian artistic practice at that time.

Salleh ben Joned later accused the Mystical Reality manifesto as containing elements of juvenile bullying. When he acted by 'opening up his zipper and zipped his mouth shut,' and water the exhibition catalog with his urine - Salleh can be seen as representing the art world institution itself and the incident can actually be examined as indirectly conferring the status of the objects on display as artworks. His urine had symbolically conferred these objects or artifacts as artworks in the art world, formally and legally at one corner of the Writer's Corner in DBP. Salleh who was also a credential agent of the art world institutions claimed his act was also inspired by the Zen spirit. Salleh himself was apt as a poet/writer who comes from literature background. Therefore, this incident can also be argued as a very brave cross-disciplinary interaction: a protest against what he saw as hypocrisy, conflict and as a challenge towards the ideas that was brought forward by the manifesto. The explicit and implicit credential of Salleh as a poet/writer was then further revealed in response to the open letter that was later 
published in Dewan Sastera. He analyzed the Zen concept deeper than what had been articulated by the manifesto. Salleh explained that he was practically illustrating a Zen master's anecdote who licked the buttock of a monk as an Enlightenment metaphor (Joned, 1975: 59). The challenges and symbolic act made by Salled as he peed on the catalogue can be argued as another form of conferring (anointing/consecrating) the exhibition that had increased the value of the event.

\section{Endnotes}

${ }^{1}$ Bauhaus teachings emphasise the analytical and investigative aspects of visual perception and the structural properties of visual design, rather than the emotive-intuitive approach of previous academic traditions.

2 The term Abstract Expressionist in Malaysia is employed loosely to describe the kind of work, which moves towards abstraction, or non-representational art that seems to communicate exclusively through formal means of line, shape, colour, space, and texture and physical aspects such as brush strokes. These abstracted forms and colours are produced to communicate their emotional and spiritual states. The association of the artists labelled as Abstract Expressionists culminated in a group exhibition called GRUP in 1967 at the former AIA Insurance Building on Ampang Road. This was followed by another exhibition entitled The Expressionists of the 1960s in 1974.

${ }^{3}$ The work was "The Fountain" (1917) by Marcel Duchamp.

\section{References}

Abdullah, S. (2008). Malaysian postmodern art and its strategies. In S. Lee \& H. Chan (Eds.), New Asian Imagination. Singapore: Nanyang Academy of Fine Arts.

Abdullah, S. (2010a). The early postmodern artistic strategies in Malaysian Art. In sentAp! , no. 01/07.

Abdullah, S. (2010b). Absenteeism of Malaysian identity in art in the early years of independence. Journal of Southeast Asian Studies (JATI), 15(1).

Abdullah, S. (2011). Thematic approaches in Malaysia Art since the 1990s. Journal of Southeast Asian Studies (JATI), 16(1).

Abdullah, S. (2013). Contextualizing abstraction and abstract expressionist art in Malaysia. In H. Hussin, M. R. M. Ariff, L.B. Bautista, R.C. Jubilado, C. Yun, D. Quintero \& W.Q J.R. Javier (Eds.), 5th International Conference on Southeast Asia (ICONSEA 2013). University of Malaya: Department of Southeast Asian Studies, University of Malaya.

Amin, P. (1975). Surat terbuka polemik senilukis. In Dewan Sastra 5, no. 8. 
Danto, A. C. (1996). Art, essence, history, and beauty: A reply to carrier, a response to Higgins. Journal of Aesthetics and Art Criticism 54, no. 3 (Summer 1996).

Danto, A. C. (2007). Arthur Danto: The artworld. In T.E. Wartenberg (Ed.), The nature of art. CA: Thomson Wadsworth.

Dickie, G. (2007). George Dickie, art and the aesthetics: An institutional analysis. In T.E. Wartenberg (Ed), The nature of art. CA: Thomson Wadsworth.

Ismail, S. Z. (1975). Suatu esei untuk Piyadasa. In Dewan Sastra 5, no. 5.

Kuala Lumpur. (1970). Experiment '70.

Joned, S. B. (1975). Kencing dan kesenian. Dewan Sastra 5, no. 7: 56-59.

Lebel, R. (1959). Marcel Duchamp. New York: Paragraphic Books.

Mashadi, A. (2007). Telah terbit (out now): Southeast Asia contemporary art practices during the 1960s to 1980s (2007). Singapore: Singapore Art Mudeum.

Piyadasa, R. (1972). Statements by Redza Piyadasa about his work. In Dokumentasi 72: Recent works by Sulaiman Esa and Redza Piyadasa. Kuala Lumpur: Samat Art Gallery.

Piyadasa, R. \& Suleiman E. (1974). Towards a mystical reality: A documentation of jointly initiated experiences by Redza Piyadasa and Suleiman Esa. Kuala Lumpur.

Piyadasa, Redza (1975). Satu lagi jawaban untuk Siti Zainon. In Dewan Sastra 5, no. 6.

Sabapathy, T.K. Piyadasa. (1978) Kuala Lumpur: Archipelago Publishers.

Sabapathy, T.K. (Ed.) (1994). Vision and idea: Relooking modern Malaysian art. Kuala Lumpur: National Art Gallery.

Soon, S. (2013). An empty canvas on which many shadows have already fallen. In N.H. Khairuddin, B. Yong \& Sabapathy, T.K. (Eds.), Reaction -- New critical strategies: Narratives in Malaysian art. Kuala Lumpur: RogueArt. 